\title{
Due To
}

National Cancer Institute

\section{Source}

National Cancer Institute. Due To. NCI Thesaurus. Code C89272.

Caused by or resulting from. 